\title{
ADAPTATION PATHWAY FOR A BARRIER ISLAND TO FUTURE HURRICANES
}

\author{
Stephanie M. Smallegan ${ }^{1}$ and Evan Mazur ${ }^{2}$
}

\begin{abstract}
The numerical model XBeach is used to simulate hydrodynamics and morphological change of Bay Head, NJ, which is located on a developed barrier island. Bay Head is fronted with a seawall buried beneath its dunes, and the seawall has been shown to mitigate damage due to storm surge and waves during Hurricane Sandy (2012). The objective of this study is to re-evaluate the effectiveness of the seawall in mitigating damage from a synthetic storm and sea level rise, and refine an adaptation pathway previously created for Bay Head. Utilizing the wave and surge data generated from the North Atlantic Coast Comprehensive Study, synthetic Storm 391 is simulated using XBeach. Model results show the seawall is overtopped by storm surge and waves, causing overwash and reducing dune heights. As sea levels rise, the backbarrier region of the barrier island is severely eroded and the seawall acts as a barrier preventing elevated bay water levels from freely flowing across the island and into the ocean, exacerbating sediment transport on the backbarrier. To fully evaluate the capabilities and limitations of the seawall in mitigating storm damage, additional synthetic storms need to be simulated and the results re-evaluated. This will, in turn, lead to a comprehensive, more robust adaptation pathway for Bay Head.
\end{abstract}

Keywords: barrier island; sea level rise; adaptation strategy; XBeach

\section{INTRODUCTION}

Approximately $6.5 \%$ of the world's coastlines comprise barrier islands, totaling over $15,000 \mathrm{~km}$ in length (Stutz and Pilkey, 2001). These often narrow, low-lying landforms are exposed to wave and tidal action and are sensitive to changes in sea levels. They provide critical ecological services and serve as the first line of defense for the mainland coast against coastal hazards. During periods of high-energy seas and elevated water levels, such as during hurricanes, barrier islands can experience extreme morphological changes (Figure 1). These processes can be described using the four storm impact regimes as described by Sallenger (2000): the swash, collision, overwash and inundation regimes. Of these, overwash (the onshore transport of sand from the dunes and beach) and inundation (completely submerged island; often a channel or inlet is created through the barrier island) are typically most destructive.

As sea levels rise, storm impacts on barrier islands are expected to become more severe. The global rate of sea level rise (SLR) is measured as $1.7 \mathrm{~mm} / \mathrm{y}$ since 1900, with more recent data $(1993$ - 2009) showing a higher rate of $2.8 \mathrm{~mm} / \mathrm{y}$ from in situ measurements (Church and White, 2011). Water levels estimated from satellite data show an even higher rate of $3.2 \mathrm{~mm} / \mathrm{y}$. Projected global SLR ranges from $0.3 \mathrm{~m}$ to $2.5 \mathrm{~m}$ by 2100 (Sweet et al., 2017). Along the U.S. Atlantic and Gulf of Mexico coasts, sea levels are rising, with many locations experiencing relative sea level rise rates higher than even the higher global average rate ("Sea Level Trends," 2018).

On developed barrier islands, the interactions between hydrodynamics and sediment transport with existing infrastructure (buildings, roadways, etc.) further complicate the impacts of coastal storms and sea level rise. By length, barrier islands along the U.S. Atlantic and Gulf of Mexico coasts comprise $24 \%$ of the 15,000 km total (Stutz and Pilkey, 2001), and many of these islands are developed with civil infrastructure. A barrier island's natural response to storms and sea level rise is to migrate landward, decrease in island width and height, or overwash and breach more frequently (Gutierrez et al., 2007). However, this response is typically altered or even prevented on developed barrier islands. Historically, beach nourishment has been used as a common adaptation strategy to reduce the impacts of ocean waves and storm surge. Hard structures, such as seawalls, are also common and have been used in conjunction with nourishment or as stand-alone structures.

Although each strategy has its own benefits and impacts, the "cost" (e.g. economic, ecological, environmental, social) of each is different and will likely change in the future climate. Smallegan et al. (2017) evaluated the effectiveness of several adaptation strategies to mitigate the damage caused by a Hurricane Sandy-like storm and SLR on a developed barrier island in New Jersey. The results are compiled in an adaptation pathway, which indicates the most effective adaptation strategy for a given level of SLR, and shows that for SLR greater than $0.2 \mathrm{~m}$ beach nourishment alone is not effective at

\footnotetext{
${ }^{1}$ Assistant Professor, Civil, Coastal, and Environmental Engineering, University of South Alabama, 150 Jaguar Drive, Mobile, Alabama, 36688, United States

2 Undergraduate Student, Civil, Coastal, and Environmental Engineering, University of South Alabama, 150 Jaguar Drive, Mobile, Alabama, 36688, United States
} 
mitigating storm damage on the barrier island (as compared to damage experienced from Hurricane Sandy (2012)).
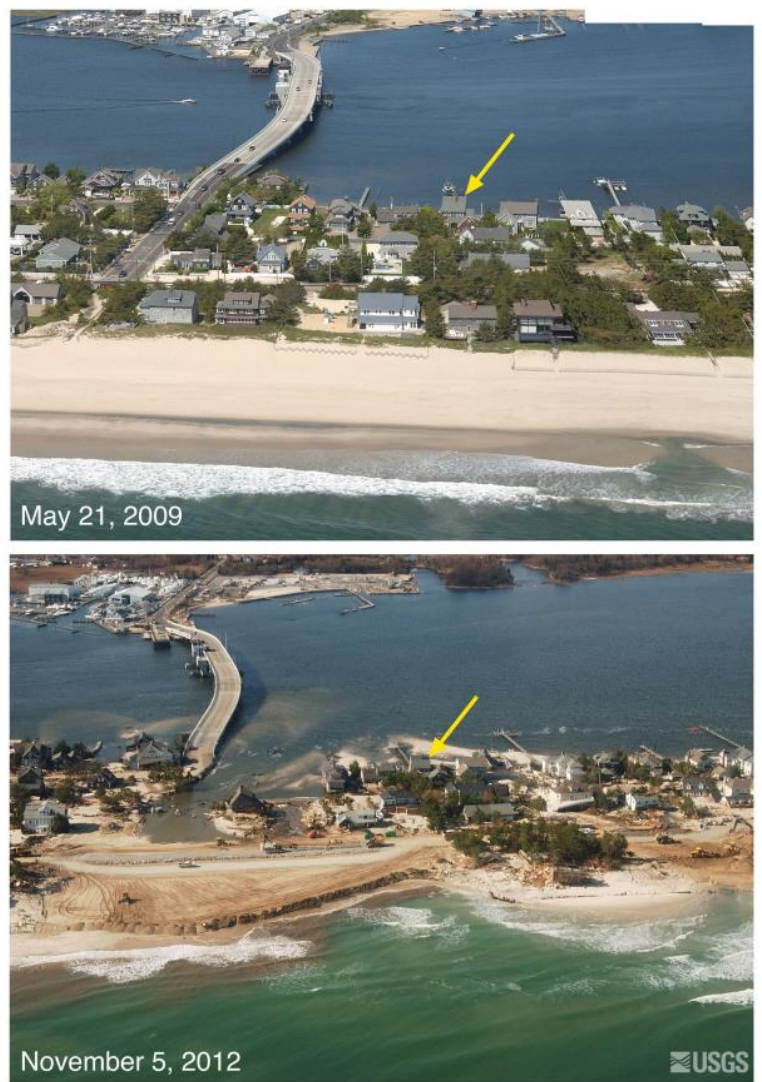

Figure 1. Aerial photographs of Mantoloking, NJ (top) before and (bottom) after Hurricane Sandy. Damage due to a breach near the bridge is being repaired; the yellow arrows point to a common feature in the photos (USGS, 2012).

The purpose of this study is to evaluate the impacts of hurricanes and sea level rise on a developed barrier island using a morphodynamic numerical model. The analysis presented in Smallegan et al. (2017) is further developed by simulating a synthetic storm in addition to Hurricane Sandy under future sea levels and re-evaluating the effectiveness of adaptation strategies, specifically its buried seawall, in mitigating damage to the New Jersey barrier island during future storms. The objectives of this ongoing study is to refine the adaptation pathway by including additional storms in the analyses that lead to its creation, and establish a meaningful level of accuracy for its use as a planning tool rather than a predictive tool.

\section{METHODS}

\section{Study Site}

Bay Head is located approximately $2.5 \mathrm{~km}$ north of Mantoloking (Figure 1; north is to the right) on a developed barrier island in New Jersey. On 29 October 2012, Hurricane Sandy made landfall about $85 \mathrm{~km}$ south of Bay Head near Atlantic City, NJ. The nicknamed "Superstorm Sandy" was unusually large with a radius of $280 \mathrm{~km}$ and maximum sustained winds of $130 \mathrm{~km} / \mathrm{h}$ at landfall. Although both Bay Head and Mantoloking experienced severe flooding due to Hurricane Sandy, Mantoloking was breached in several locations (Figure 1), whereas damage in Bay Head was significantly reduced by its armored dune. According to numerical studies, the rock seawall buried beneath the nourished dunes in Bay Head reduced wave impacts by a factor of two (Irish et al., 2013; Smallegan et al., 2016).

To evaluate the continued effectiveness of the buried seawall at mitigating damage, another numerical modeling study considered a storm comparable to Hurricane Sandy and several sea level rise scenarios (Smallegan et al., 2017). As expected, the simulations showed increases in erosion and 
decreases in the seawall's effectiveness as sea levels rose. Therefore, other adaptation strategies were considered, such as raising the beach by SLR through beach nourishment, for SLR of $0.2 \mathrm{~m}, 1.0 \mathrm{~m}$ and $2.2 \mathrm{~m}$ (the relative SLR rate at Bay head is $4.1 \mathrm{~mm} / \mathrm{y}$ ("Sea Level Trends," 2018) and the SLR scenarios correspond to projections by Parris et al. (2012)). These results were compiled into an adaptation pathway, which is a responsive planning tool used to map the appropriate adaptation strategy for the level of SLR observed (Smallegan et al., 2017). As previously stated, beach nourishment is a common adaptation strategy, and Bay Head has nourished its beaches several times in the past, re-burying the seawall each time. However, Smallegan et al. (2017) shows for SLR greater than $0.2 \mathrm{~m}$, beach nourishment becomes ineffective at mitigating storm damage even with the inclusion of the rock seawall.

\section{Numerical Model Setup}

This study expands the suite of simulated storms from only Hurricane Sandy (Smallegan et al., 2017) to several synthetic storms using XBeach. The numerical model XBeach is used to simulate the effectiveness of the buried seawall at mitigating damage in Bay Head during future hurricanes considering several SLR scenarios. XBeach is a process-based model capable of accurately simulating hydrodynamics and morphological change on developed barrier islands and reproducing the four storm impact regimes (McCall et al., 2010; Roelvink et al., 2009; Smallegan et al., 2016). It has been validated for Bay Head based on post-storm surveys conducted after Hurricane Sandy and performed with a Brier Skill Score of 0.86 (1.0 indicates perfect agreement between post-survey data and simulated bed levels) (Smallegan et al., 2016). XBeach is particularly well-suited for this numerical study because of its ability to simulate hydrodynamics and morphology around buildings, which are input as "non-erodible" layers (Figure 2). The buried seawall and buildings in Bay Head are represented in the model using this feature (Figure 3).

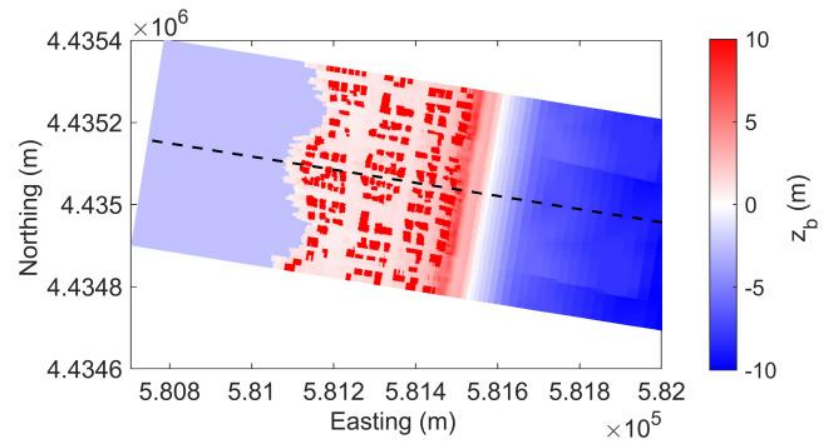

Figure 2. Two-dimensional XBeach grid of Bay Head, NJ. The offshore boundary in the Atlantic Ocean is on the right, and Barnegat Bay is on the left. The red polygons represent buildings as non-erodible layers.

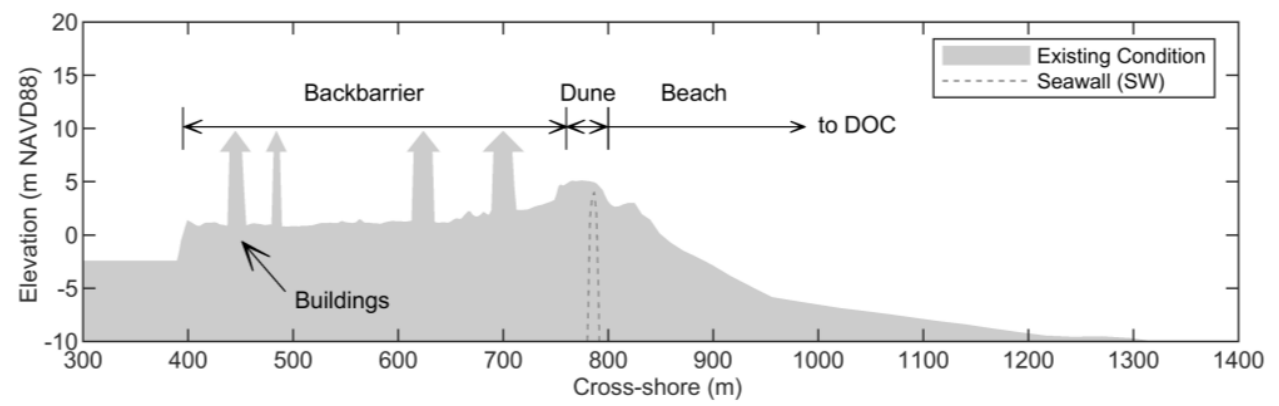

Figure 3. Representative cross-shore profile from the XBeach grid for the pre-storm topography (Existing Condition). The direction to the depth of closure (DOC) is indicated. The seawall is buried beneath the dune and is represented with buildings as non-erodable layers.

As an expansion of the work by Smallegan et al. (2017), this project considers several synthetic storms developed by the North Atlantic Coast Comprehensive Study (NACCS; Cialone et al., 2015). The NACCS suite of 1,050 synthetic storms were designed to encompass a statistically-comprehensive 
set of storms that could practically occur. These were accessed through the Coastal Hazards System (CHS; Melby and Green, 2015). Each storm is forced on the same XBeach grid used to represent the buried seawall (Figure 2). The two-dimensional grid has spatially varying cell sizes ranging from $2 \mathrm{~m}$ on land to $50 \mathrm{~m}$ offshore (Smallegan et al., 2016).

Because it is not feasible to simulate all 1,050 NACCS storms, a subset of storms is chosen based on the hydrodynamics. For example, the NACCS storm discussed herein is Storm 391 and is chosen because it has the maximum wave height in the record. Wave data time series are extracted from CHS at STWAVE save point 1046, and wave angles are converted from the local coordinate system to a nautical convention (direction where waves come from measured clockwise from North; Figure 4). The model grid is slightly altered such that the offshore water depths equal the water depth of $9.8 \mathrm{~m}$ at the save point. Water level data are extracted from ADCIRC save points 5825 at the offshore boundary and 13704 at the onshore boundary located in Barnegat Bay using the "Base conditions + 1 tide" output from CHS (Figure 5).

Comparing the wave and water level data of the two storms, Storm 391 is a 48-hour storm and 26 hours shorter than Hurricane Sandy. At the peak of Storm 391, significant wave height, $H_{s}$, is $7.8 \mathrm{~m}$, wave period, $T_{p}$, is $18 \mathrm{~s}$, and wave direction, $\theta$, is $112^{\circ}$, where $110^{\circ}$ is approximately shore-normal. However, Hurricane Sandy wave conditions at the offshore depth are less energetic with a peak $H_{s}$ of $6.5 \mathrm{~m}, T_{p}$ of $16 \mathrm{~s}$, and $\theta$ of $85^{\circ}$ (Figure 4). Ocean and bay water levels for Storm 391 follow similar trends to Hurricane Sandy (Figure 5). Ocean and bay storm surge peak at $3.8 \mathrm{~m}$ and $2.4 \mathrm{~m}$, respectively, for Storm 391, which is higher than Hurricane Sandy's peak ocean surge of $2.9 \mathrm{~m}$ and peak bay surge of $2.1 \mathrm{~m}$. Although the magnitudes differ, both storm hydrographs of bay surge have a similar shape. The decrease near the peak of the storm indicates water drawdown as southward winds blow water toward the southern end of the bay. Then, a significant increase in bay surge occurs when the wind direction shifts to the north as the storm passes, pushing water toward the northern end of the bay where Bay Head is located (Figure 5).
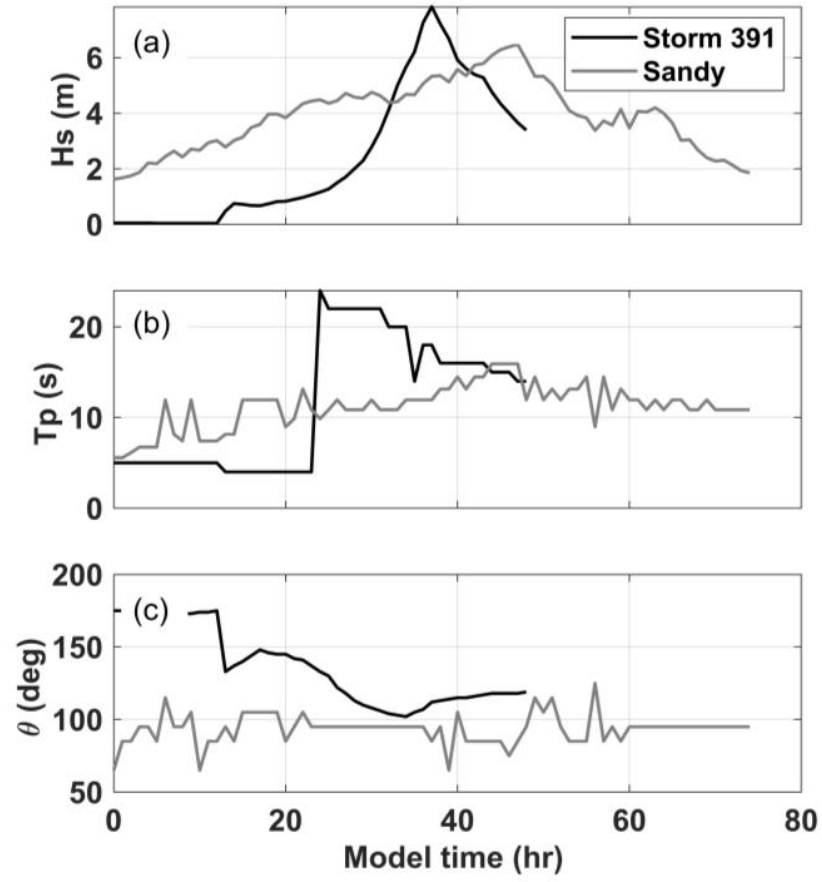

Figure 4. Time-varying XBeach inputs of (a) significant wave height, $H_{s}$, (b) peak period, $T_{p}$, and (c) wave angle, $\theta$, for NACCS Storm 391 (black) and Hurricane Sandy (gray). 

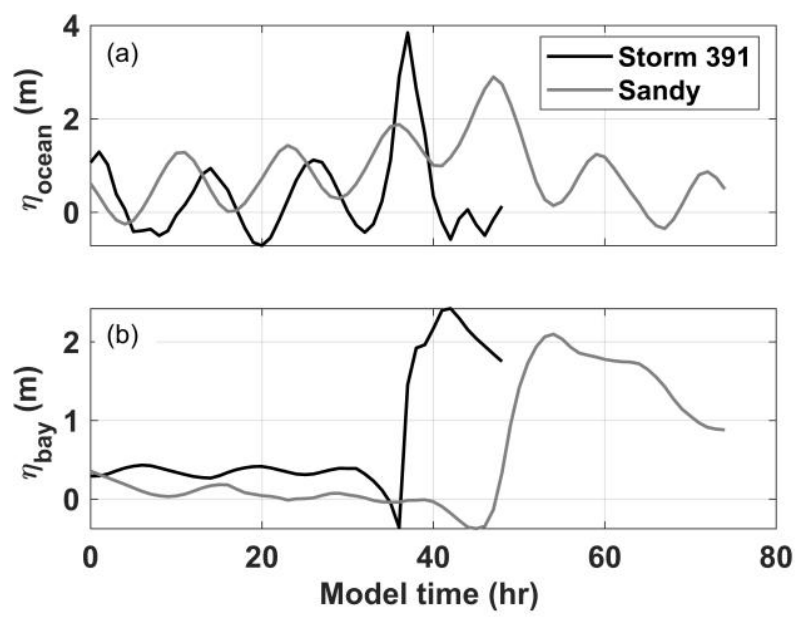

Figure 5. Water levels (a) at the offshore boundary and (b) onshore bay boundary for NACCS Storm 391 (black) and Hurricane Sandy (gray).

Following the methodology from Smallegan et al. (2017) for Hurricane Sandy, SLR scenarios of $0.2 \mathrm{~m}, 1.0 \mathrm{~m}$ and $2.2 \mathrm{~m}$ are superimposed on the storm surge for Storm 391 (Figure 6) and the storm resimulated. The maximum ocean surge simulated is $6 \mathrm{~m}$ and the maximum ocean surge is approximately $4.5 \mathrm{~m}$. Several studies have shown that storm surge is nonlinearly affected by sea levels such that amplification and deamplification of surge occurs as sea levels rise (e.g. Bilskie et al., 2014; Taylor et al., 2015). Here, it is acknowledged that this is a limitation of this study but is chosen for simplicity in comparison between storms and the resulting morphological changes.

In this study, the results of previous work that simulated the morphological change due to Hurricane Sandy and three SLR scenarios for the existing condition (i.e. the buried seawall as it existed prior to Hurricane Sandy) are compared to the simulated morphological change of Storm 391 under the same SLR scenarios and topographic conditions. By including several synthetic storms in addition to Hurricane Sandy in the creation of the adaptation pathway, the analyses of future storm impacts on developed barrier islands and the effectiveness of adaptation strategies under a changing climate becomes more robust.
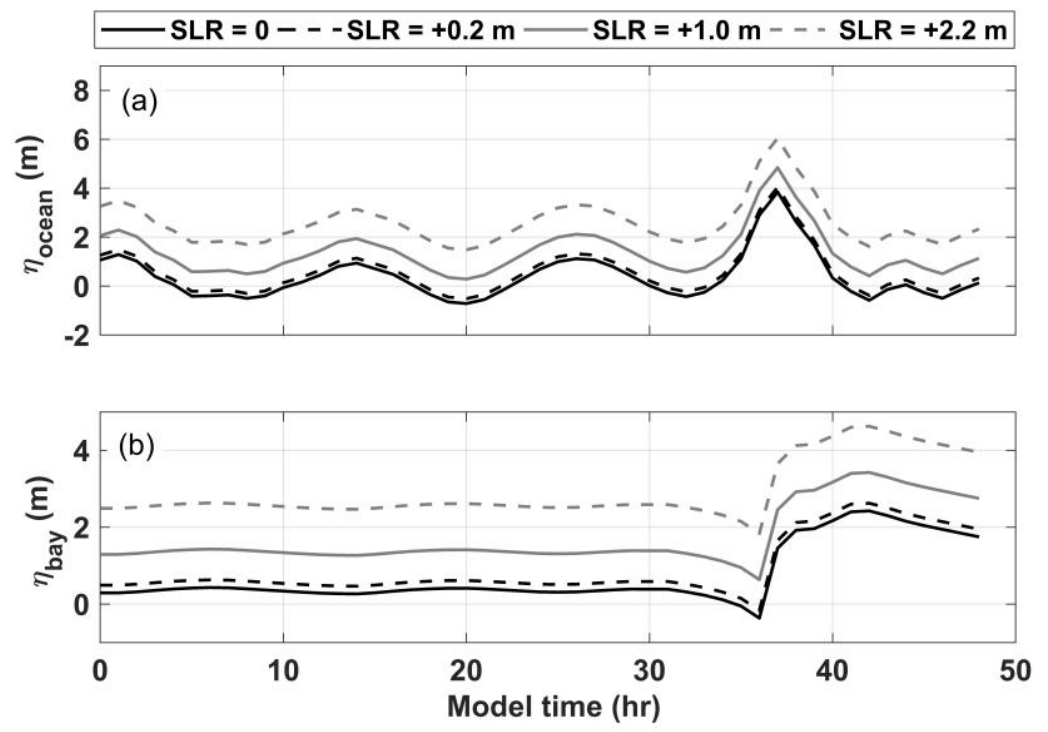

Figure 6. Water levels (a) at the offshore boundary and (b) onshore bay boundary for NACCS Storm 391 with $\mathrm{SLR}=0$ (black), SLR = +0.2 m (black dashed), SLR = +1.0 m (gray), and SLR = +2.2 $\mathrm{m}$ (gray dashed). 


\section{RESULTS}

The morphological change at Bay Head due to Storm 391 and three SLR scenarios are simulated using XBeach. Comparing the results of Storm 391 to Hurricane Sandy, XBeach simulates erosion of the berm on the seaward side of the seawall (approximate Easting of $581520 \mathrm{~m}$; Figure 7) for both storms. However, the dune is overwashed during Storm 391 causing a decrease of about $7 \mathrm{~m}$ in height at the dune peak. Morphological change on the backbarrier is comparable between storms with Storm 391 showing a slight increase in elevations due to sediment deposits from the overwash (Figure 7).

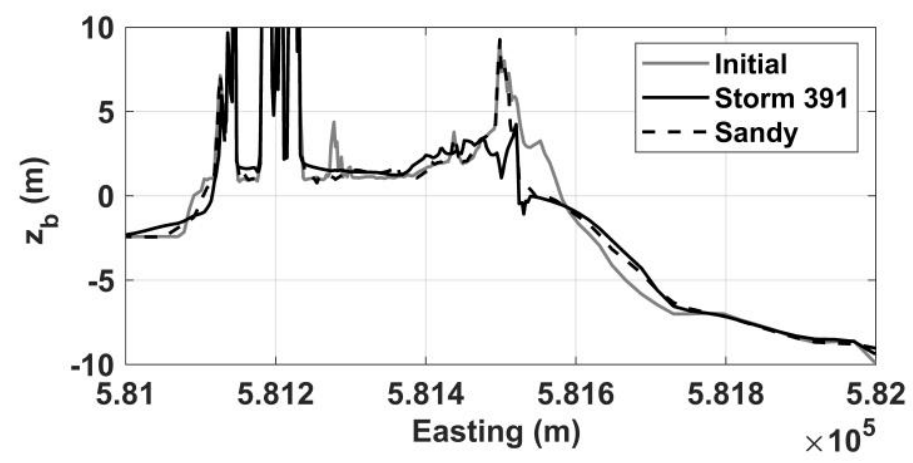

Figure 7. Cross-shore profiles of the initial topography (gray) and the final simulated topography for Storm 391 (black) and Hurricane Sandy (black dashed). Building are represented as spikes in the data.

To evaluate the impacts of Storm 391 in the future climate, SLR scenarios of $0.2 \mathrm{~m}, 1.0 \mathrm{~m}$, and 2.2 $\mathrm{m}$ are superimposed on the ocean and bay water levels and the storm re-simulated. As expected, the morphological change, particularly on the island's backbarrier, increases as water levels increase (Figure 8). Under all SLR scenarios, the berm is completely eroded and the seawall is exposed. The morphological change on the backbarrier is comparable for all SLR scenarios except $2.2 \mathrm{~m}$, which causes severe erosion and decreases in elevation up to about $5 \mathrm{~m}$.

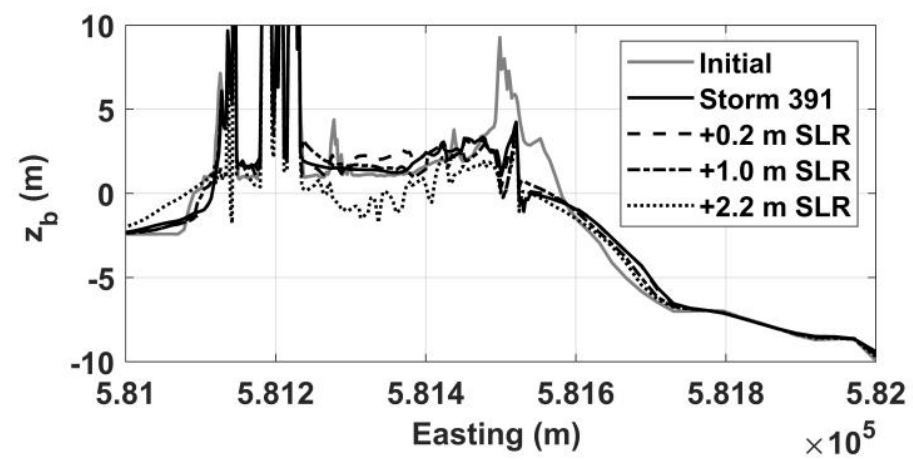

Figure 8. Cross-shore profiles of the initial topography (gray) and the final simulated topography for Storm 391 (black), Storm 391 with $+0.2 \mathrm{~m}$ of SLR (black dashed), Storm 391 with $+1.0 \mathrm{~m}$ of SLR (black dash-dot), and Storm 391 with $+2.2 \mathrm{~m}$ of SLR (black dotted). Building are represented as spikes in the data.

The simulated topography of Bay Head due to Storm 391 and Hurricane Sandy under SLR scenarios of $0.2 \mathrm{~m}, 1.0 \mathrm{~m}$, and $2.2 \mathrm{~m}$ are shown in Figure 9. For SLR of $0.2 \mathrm{~m}$, XBeach simulates similar morphological change as with no SLR resulting in a final profile that follows a similar trend to that described previously (Figure 9 (a)). For this conservative SLR scenario, sediment is eroded from the seaward side of the seawall during both storms; however, the dunes are overwashed only during Storm 391. At other locations in the domain, the $0.2 \mathrm{~m}$ of SLR superimposed on Hurricane Sandy storm surge results in decreases in dune heights from overwash, but the extent of the overwash is significantly less compared to Storm 391.

For SLR of $1.0 \mathrm{~m}$, the dunes are overwashed during both Storm 391 and Hurricane Sandy (Figure 9 (b)). Morphological change on the backbarrier is relatively low, but elevations are lower after the Hurricane Sandy +1.0 m SLR simulation compared to the Storm $391+1.0 \mathrm{~m}$ SLR simulation. This response is exacerbated by the superposition of the $2.2 \mathrm{~m}$ SLR scenario on both storm's surges (Figure 
9 (c)). Dune heights and backbarrier elevations are severely lowered during Hurricane Sandy, and the sediment is transported and deposited into Barnegat Bay (Easting less than $581100 \mathrm{~m}$ ). Likewise, the Storm $391+2.2 \mathrm{~m}$ SLR simulation shows significant decreases in backbarrier elevations, but the erosion, likely due to scour, behind the seawall is less severe than the Hurricane Sandy simulation (approximately Easting of $581520 \mathrm{~m}$ ). The deep scour hole due to Hurricane Sandy $+2.2 \mathrm{~m}$ SLR would likely cause damage to the seawall; however, XBeach does not currently have the capability to damage or destroy structures that are represented as "non-erodible" layers.
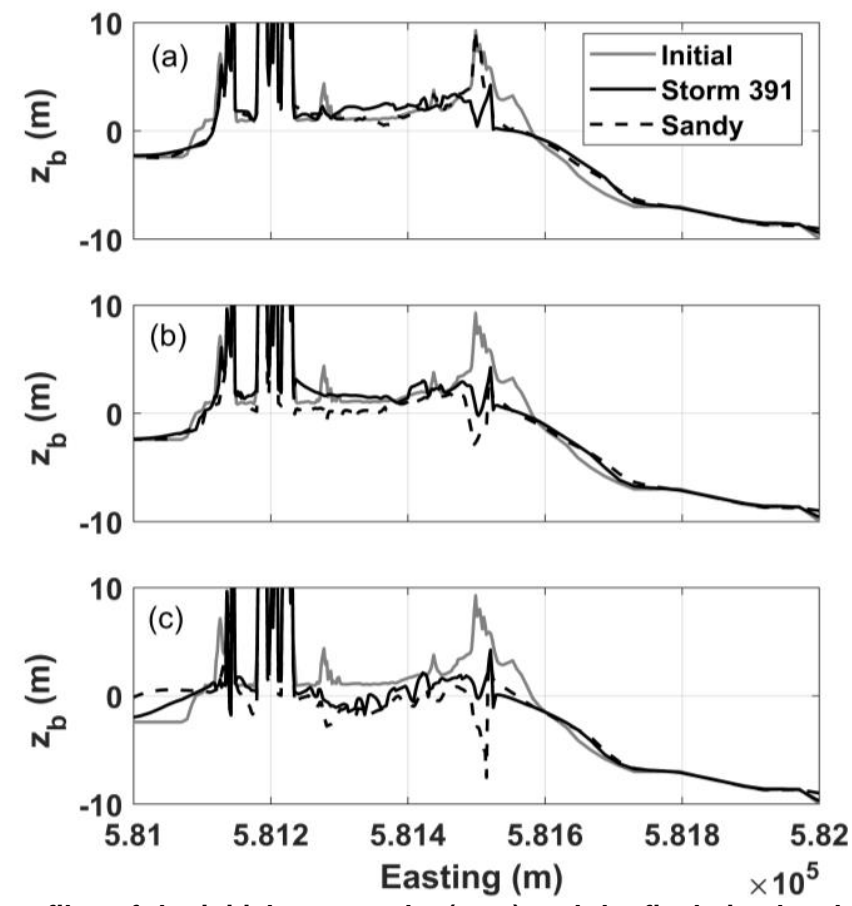

Figure 9. Cross-shore profiles of the initial topography (gray) and the final simulated topography for Storm 391 (black) and Hurricane Sandy (black dashed) for (a) $S L R=0.2 \mathrm{~m}$, (b) $S L R=1.0 \mathrm{~m}$, and (c) $S L R=2.2 \mathrm{~m}$. Building are represented as spikes in the data.

\section{DISCUSSION}

Storm 391 is simulated as a storm 26 hours shorter than Hurricane Sandy. However, its wave heights and storm surge are $1.3 \mathrm{~m}$ and $1.1 \mathrm{~m}$ larger, respectively, resulting in overwashed dunes and a seawall exposed on both its sea and landward sides. Therefore, the threshold condition for dune overtopping and overwash (Sallenger, 2000) is met by the hydrodynamic forcing conditions for Storm 391 but not Hurricane Sandy, according to XBeach simulations. The larger wave heights and higher water levels that characterize Storm 391 are able to overtop the dunes and fully expose both sides of the seawall, whereas Hurricane Sandy was able to expose only the front side of the seawall despite the extended period of elevated water levels due to its relatively long duration.

Considering SLR with Storm 391, XBeach simulations show increases in the erosion behind the seawall (landward side) as sea levels rise. On the seaward side of the seawall, morphological change between SLR scenarios remains relatively constant for Storm 391; the higher water levels do not cause an increase in erosion on the front face of the seawall. The effects of SLR are, instead, evident in the erosion that results on the backbarrier. For Storm 391, the dunes are overwashed by ocean waves and surge and the sediment is deposited on the backbarrier. Then, the backbarrier is inundated by elevated bay surge and some of the sediment deposits are transported into the bay. For SLR of $2.2 \mathrm{~m}$, this sediment transport results in erosion of both the sediment deposits due to overwash and of sediment pre-existing on the backbarrier. In this case, the seawall prevents bay surge from flowing freely over the island and to the ocean during elevated bay water levels. As the bay water levels recede, sediment is transported back into the bay, resulting in severe erosion and decreases in backbarrier elevations. This response was also observed in a numerical study on the effect of bay water levels on the morphological change at Bay Head (Smallegan and Irish, 2017). In that study, erosion on the backbarrier occurred 
when bay water levels were higher than ocean water levels, and erosion increased as bay water levels increased.

Comparing Storm 391 and Hurricane Sandy with SLR scenarios superimposed on the water levels, the morphological change is similar between the storms such that erosion increases as sea levels rise. For a conservative amount of SLR $(0.2 \mathrm{~m})$, XBeach simulates similar morphological change as the no SLR scenario. However, for SLR greater than $0.2 \mathrm{~m}$, Hurricane Sandy causes more erosion on the landward side of the seawall compared to Storm 391 and larger sediment deposits in the bay. This is likely due to continued wave overtopping the seawall after the peak of the storm when ocean water levels are receding and bay water levels are rising. This is also observed for Storm 391 but only for a short duration since wave heights decrease more rapidly after the peak of the storm compared to Hurricane Sandy.

As indicated by these results, Bay Head has a similar morphological response to Storm 391 and Hurricane Sandy and a similar trend is observed in the morphological change as sea levels rise. However, the seawall is less effective at mitigating damage from Storm 391 due to its higher wave heights and water levels that are able to overtop the dunes, leading to a significant decrease in dune heights. As sea levels rise, the seawall's effectiveness decreases and even serves as a barrier preventing bay water levels from freely flowing over the barrier island to the ocean, which in turn causes more erosion on the backbarrier when bay water levels recede.

\section{CONCLUSIONS}

This numerical modeling study simulates morphological change at Bay Head, NJ for a synthetic storm considering sea level rise and evaluates the effectiveness of a buried seawall in mitigating storm damage in terms of erosion. These results are compared to Hurricane Sandy simulations of morphological change previously conducted. From XBeach simulations of NACCS Storm 391 and several SLR scenarios, the effectiveness of the buried seawall in Bay Head decreases as storm surge and waves increase and sea levels rise. However, Storm 391 has the largest wave heights in the NACCS record of storms, representing a severe hurricane with likely a lower probability of occurring. Therefore, additional storms of varying intensity should be simulated to more comprehensively evaluate the seawall's effectiveness at reducing storm damage. Future work will also consider adaptation strategies, such as beach nourishment, and their impacts on morphological change due to the synthetic storms and SLR. These results will be used to re-evaluate the adaptation pathway previously created for Bay Head, NJ.

\section{ACKNOWLEDGEMENTS}

The authors would like to thank the University of South Alabama's College of Engineering and Office of Undergraduate Research for sponsoring this research and travel to ICCE 2018. We also acknowledge the Alabama Supercomputer Authority for providing the computational power needed to complete the model simulations.

\section{REFERENCES}

Bilskie, M.V., Hagen, S.C., Medeiros, S.C., Passeri, D.L., 2014. Dynamics of sea level rise and coastal flooding on a changing landscape. Geophys. Res. Lett. 41, 927-934. https://doi.org/10.1002/2013GL058759

Church, J.A., White, N.J., 2011. Sea-Level Rise from the Late 19th to the Early 21st Century. Surv. Geophys. 32, 585-602. https://doi.org/10.1007/s10712-011-9119-1

Cialone, M.A., Massey, T.C., Anderson, M.E., Grzegorzewski, A.S., Jensen, R.E., Cialone, A., Mark, D.J., Pevey, K.C., Gunkel, B.L., McAlpin, T.O., 2015. North Atlantic Coast Comprehensive Study (NACCS) coastal storm model simulations: Waves and water levels. Engineer Research and Development Center, Vicksburg, MS, Coastal and Hydraulics Lab.

Gutierrez, B.T., Williams, S.J., Thieler, E.R., 2007. Potential for shoreline change due to sea-level rise along the US Mid-Atlantic region.

Irish, J.L., Lynett, P.J., Weiss, R., Smallegan, S.M., Cheng, W., 2013. Buried relic seawall mitigates Hurricane Sandy's impacts. Coast. Eng. 80, 79-82. https://doi.org/10.1016/j.coastaleng.2013.06.001

McCall, R.T., Van Thiel de Vries, J.S.M., Plant, N.G., Van Dongeren, A.R., Roelvink, J.A., Thompson, D.M., Reniers, A.J.H.M., 2010. Two-dimensional time dependent hurricane overwash and 
erosion modeling at Santa Rosa Island. Coast. Eng. 57, 668-683. https://doi.org/10.1016/j.coastaleng.2010.02.006

Melby, J.A., Green, D., 2015. Coastal hazards system. Coast. Hazards Syst. CHS Web Tool-User Guide US Army Eng. Res. Dev. Cent. Vicksbg. MS.

Parris, A.S., Bromirski, P., Burkett, V., Cayan, D.R., Culver, M.E., Hall, J., Horton, R.M., Knuuti, K., Moss, R.H., Obeysekera, J., 2012. Global sea level rise scenarios for the United States National Climate Assessment.

USGS, 2012. Pre- and Post-Storm Photo Comparisons for New Jersey - Hurricane Sandy - National Assessment of Storm-Induced Coastal Change Hazards. URL https://coastal.er.usgs.gov/hurricanes/sandy/photo-comparisons/newjersey.php (accessed 11.29.18)

Roelvink, D., Reniers, A., van Dongeren, A., van Thiel de Vries, J., McCall, R., Lescinski, J., 2009. Modelling storm impacts on beaches, dunes and barrier islands. Coast. Eng. 56, 1133-1152. https://doi.org/10.1016/j.coastaleng.2009.08.006

Sallenger, A.H., 2000. Storm Impact Scale for Barrier Islands. J. Coast. Res. 16, 890-895.

Sea Level Trends, 2018. NOAA Tides Curr. URL https://tidesandcurrents.noaa.gov/sltrends/sltrends.html (accessed 11.29.18).

Smallegan, S.M., Irish, J.L., 2017. Barrier Island Morphological Change by Bay-Side Storm Surge. J. Waterw. Port Coast. Ocean Eng. 143, 04017025. https://doi.org/10.1061/(ASCE)WW.19435460.0000413

Smallegan, S.M., Irish, J.L., van Dongeren, A.R., 2017. Developed barrier island adaptation strategies to hurricane forcing under rising sea levels. Clim. Change 143, 173-184. https://doi.org/10.1007/s10584-017-1988-y

Smallegan, S.M., Irish, J.L., Van Dongeren, A.R., Den Bieman, J.P., 2016. Morphological response of a sandy barrier island with a buried seawall during Hurricane Sandy. Coast. Eng. 110, 102110. https://doi.org/10.1016/j.coastaleng.2016.01.005

Stutz, M.L., Pilkey, O.H., 2001. A Review of Global Barrier Island Distribution. J. Coast. Res. 15-22.

Sweet, W.V., Kopp, R.E., Weaver, C.P., Obeysekera, J., Horton, R.M., Thieler, E.R., Zervas, C., 2017. Global and regional sea level rise scenarios for the United States.

Taylor, N.R., Irish, J.L., Udoh, I.E., Bilskie, M.V., Hagen, S.C., 2015. Development and uncertainty quantification of hurricane surge response functions for hazard assessment in coastal bays. Nat. Hazards 77, 1103-1123. https://doi.org/10.1007/s11069-015-1646-5 